\title{
POPULATION BIOLOGY OF Stellifer rastrifer, S. brasiliensis AND S. stellifer IN CARAGUATATUBA BAY, NORTHERN COAST OF SÃO PAULO, BRAZIL
}

\author{
Maíra Pombo, Marcia Regina Denadai and Alexander Turra \\ Instituto Oceanográfico da Universidade de São Paulo \\ (Praça do Oceanográfico, 191, 05508-120 São Paulo, SP, Brasil) \\ *Corresponding author: mpombo@usp.br
}

\begin{abstract}
A B S T R A C T
Ecosystems may reflect environmental changes in many respects, from the debilitation of individuals to alterations in community composition. Equally, population parameters may provide reliable indications of environmental changes. Members of the sciaenid fish genus Stellifer are usually very abundant where they occur, often with two or more species living in sympatry. Here, the population dynamics of three Stellifer species from southeastern Brazil were assessed. Sampling was carried out in shallow marine areas of Caraguatatuba Bay, from August 2003 to October 2004. The species evaluated were Stellifer rastrifer $(\mathrm{n}=3183)$, S. brasiliensis $(\mathrm{n}=357)$ and S. stellifer $(\mathrm{n}=116)$. The area under greater continental influence tended to support more, but smaller individuals. Size variations over time were similar among species and negatively correlated with Krel, which showed smooth fluctuations. The general length-frequency distribution was concentrated between 6.0 and $9.0 \mathrm{~cm}$, and the great majority of females did not present mature gonads during the sampling period. The findings support the existence of a stratification by size for these species, indicating that the area is essential for the development of younger fish. Failure to consider these characteristics for the management of similar areas may have serious implications for these environments.
\end{abstract}

\section{RESUMO}

Os ecossistemas podem refletir mudanças ambientais em muitos aspectos, desde o enfraquecimento dos indivíduos até alterações na composição da comunidade. Do mesmo modo, os parâmetros populacionais podem fornecer indicações confiáveis de mudanças ambientais. Sciaenídeos do gênero Stellifer são peixes geralmente muito abundantes e em suas populações é frequente a ocorrência de duas ou mais espécies simpátricas. No presente trabalho, a dinâmica populacional de três espécies de Stellifer do sudeste do Brasil foi avaliada. A amostragem ocorreu em águas rasas das zonas marinhas da Baía de Caraguatatuba, de agosto de 2003 a outubro de 2004. As espécies avaliadas foram Stellifer rastrifer $(\mathrm{n}=3.183)$, S. brasiliensis $(\mathrm{n}=357)$ e $S$. stellifer $(\mathrm{n}=116)$. Os resultados mostraram que a área sob maior influência continental tende a suportar um número maior de indivíduos menores. Variações de tamanho ao longo do tempo foram semelhantes entre as espécies e negativamente correlacionadas com o Krel, que apresentou flutuações suaves. De modo geral a distribuição de freqüência de comprimento ficou concentrada entre 6,0 e $9,0 \mathrm{~cm}$ e para a grande maioria das fêmeas as gônadas se apresentaram imaturas durante o período avaliado. Os resultados suportam a existência de estratificação populacional por tamanho dentro destas espécies, indicando que a área é apropriada para o desenvolvimento de juvenis. A desconsideração de tais características pode acarretar sérias implicações para a gestão dessas áreas.

Descriptors: Stellifer, Sympatric species, Shallow continental shelf waters, Spatio-temporal distribution, Sexual characterization, Weight-length relationship.

Descritores: Stellifer, Espécies simpátricas, Plataforma continental rasa, Distribuição espaçotemporal, Caracterização sexual, Relação peso-comprimento.

\section{INTRODUCTION}

Coastal areas have been historically important in supplying humankind with a plurality of ecosystem services. As transitional environments, they are highly susceptible to environmental changes, although frequently subjected to a wide range of anthropogenic impacts. Extensive areas of the Brazilian coast, especially near urban centers, suffer from haphazard occupation, exploitation of natural resources, predatory fishing, gas and oil production, and/or domestic and industrial pollution, among other factors (ASMUS; KITZMANN, 2004). Damage may arise from many causes and environmental quality be 
so harmed as to make remedial action ineffectual. Knowledge of populations and community dynamics, including changes in such primary characteristics as density and differential mortality, can be very useful in evaluating environmental quality. Population dynamics are an expression of an evolutionary process, the responses of a population to environmental features. Therefore, understanding how populations change through space and over time is a valuable tool for the improvement of the management of coastal areas.

In this regard, the study of sympatric species provides an important opportunity for integrated analysis of ecological and evolutionary processes. It is to be expected that closely related species will show similar responses to environmental occupation and damage, thus allowing them to be used as similar indicators. The genus Stellifer is one of the most diverse genera of the family Sciaenidae in America (SASAKI, 1989), and often one or more of its species are among the most numerous members of fish communities, mainly in the tropics and subtropics (MENEZES; FIGUEIREDO, 1980; COELHO et al., 1985; FLORES-COTO et al., 2004; BARLETTA et al., 2005; CAMARGO; ISAAC, 2005; UPCHURCH; WENNER, 2008). In Brazil, sciaenids are found from shallow mangrove swamps (CHAVES; VENDEL, 1997; BARLETTA et al., 2003) to depths of over 20 $\mathrm{m}$ (VIANNA; ALMEIDA, 2005), and are often considered as permanent residents of estuaries. Some are classified as semi-anadromous fishes, i.e, those that spawn close to estuaries, into which eggs and larvae are carried by tides (CAMARGO; ISAAC, 2005; BONECKER et al., 2007).

The heavily urbanized southeastern part of the country presents four of the six Stellifer species known on the Brazilian coast (MENEZES; FIGUEIREDO, 1980). In addition to their being an abundant, discarded seabob fishery by-catch (COELHO et al., 1985; PAIVA FILHO; SCHMIEGELOW, 1986; GIANINNI; PAIVA FILHO, 1990a), the Stellifer species are subject to all the other sorts of human impact that affect the area. The present study evaluated three of these species, $S$., S. brasiliensis and S. stellifer; the fourth, Stellifer $\mathrm{sp.}$ (c.f. MENEZES, FIGUEIREDO, 1980), is rarely caught in numbers sufficient to permit this kind of research (BARLETTA-BERGAN et al., 2002; BARLETTA et al., 2003, 2005; BARLETTA; BARLETTA-BERGAN, 2009; CAMARGO; ISAAC 2005; SCHWARZ et al., 2006). Stellifer rastrifer is found all along the Brazilian coast, in waters of from intermediate to high salinities and low to intermediate depths (GIANINNI; PAIVA-FILHO, 1990a; SANTOS et al., 2002; BARLETTA et al., 2005, 2008; CAMARGO; ISAAC, 2005; FIGUEIREDOFONSECA; LOBÃO DE SOUZA, 2006). Stellifer brasiliensis is usually associated with more saline, deeper waters, and is not found off the northern Brazilian coast (VIANNA; ALMEIDA, 2005; FREIRE et al., 2009). Stellifer stellifer is frequently observed in lower abundance than the others, but is the most widely distributed, showing apparently the highest tolerance for fluctuations in abiotic factors (ALMEIDA; BRANCO 2002; BARLETTA et al. 2003; BRANCO; VERANI 2006; FIGUEIREDOFONSECA; LOBÃO DE SOUZA 2006).

Despite the abundant evidence of their ecological value, studies assessing concomitantly the population parameters of two or more Stellifer species, which frequently coexist, are rare and usually deal with the basic characteristics of demersal fish assemblages as a whole (GIANINNI; PAIVA-FILHO 1990a; BARLETTA et al., 2003, 2005; CAMARGO; ISAAC 2005; FIGUEIREDO-FONSECA; LOBÃO DE SOUZA, 2006; SCHWARZ et al., 2006; SOUZA; CHAVES, 2007). Evaluations of weight-length relationships and condition factors are available for three species (COELHO et al., 1985, 1987; BRAGA, 1986; GIANINNI; PAIVA-FILHO, 1990b, 1995; CHAVES; VENDEL, 1997; ISAAC; MOURA, 1998; FIGUEIREDO-FONSECA; LOBÃO DE SOUZA, 2006; ALMEIDA; BRANCO, 2002; FREIRE et al., 2009), although some discrepancies among species values may lead to misinterpretation. The present study is the first to evaluate the relative condition factor (LE CREN, 1951), based on weight-length relationships. The condition factor may be a useful tool for local monitoring, because it is the recommended method for comparing the health of individuals in a population (FROESE, 2006). Environmental changes, including anthropogenic changes, may significantly affect an ecosystem in many ways, such as the health of individuals, leading to changes in morphometric ratios, the size-frequency distribution of a population, and community composition (WALTHER et al., 2002).

Most previous studies were carried out in areas greatly affected by continental influence, such as mangrove swamps and estuaries. It is important, therefore, to further investigate the role of different environments in the biology of these species. The study area includes shallow marine areas, minimally influenced by rivers and estuaries, in the bay at Caraguatatuba, the largest urban center on the northern coast of São Paulo. For three of the four Stellifer species that occur in the region, population parameters (relative abundances, length-frequency distribution and sex ratio) were compared individually and among the species, over space and time. General proportions among stages of maturation of the females were also assessed for each species. The relative condition factor was estimated monthly and compared among the species. All this information gathered concomitantly 
for co-occurring congeneric species makes the data more reliable for comparisons. The study provides important information on both the genus and this ecosystem, which is coastal, tropical and intensively exploited, with insufficient knowledge to allow effective monitoring and management.

\section{Material And Methods Study Area}

Caraguatatuba Bay $\left(23^{\circ} 37^{\prime} \mathrm{S}\right.$ to $23^{\circ} 44^{\prime} \mathrm{S}$ and $45^{\circ} 24^{\prime} \mathrm{W}$ to $45^{\circ} 26^{\prime} \mathrm{W}$ ) is about $16 \mathrm{~km}$ long and contains several sandy beaches. Two areas, each $2.0 \mathrm{x}$ $0.8 \mathrm{~km}$, homogeneous but distinct from each other, were selected for this study so as to exclude the marked influence of the rivers in the region (Fig. 1). The first or South area extends from Porto Novo to Palmeiras beaches; it has a gentler slope and is more influenced by the Juqueriquerê River, which forms a small estuary. The second or North area, located between Indaiá and Centro beaches, has a steeper slope and is influenced only by small rivers (Lagoa and Santo Antônio).

\section{Sampling Procedures}

Monthly samples were taken from August 2003 through October 2004, in accordance with the federal environmental agency responsible (IBAMADIREN No. 08/2001). Three sampling stations were randomly selected in each area, South and North, among 200 possibilities, i.e., the beach length of $2000 \mathrm{~m}$ was divided into $10-\mathrm{m}$ intervals. The position of the station was stored in the GPS at MLW (mean low water), from which a fishing boat (class G2M, $11 \mathrm{~m}$ long with a 22-HP engine) carried out 800-m trawls perpendicular to the beach, from 800 to $1600 \mathrm{~m}$ from MLW. This interval is equivalent to depths from 1 to $4 \mathrm{~m}$. The trawling speed was 1 knot. The trawls were made with two otter trawls with 2.0 $\mathrm{cm}$ mesh, mouth aperture of $1.6 \mathrm{~m}$ high and $6.0 \mathrm{~m}$ long, and bag depth of $3.5 \mathrm{~m}$. After screening and identification, Stellifer individuals, properly labeled and fixed in $70 \%$ ethanol, were separated for population studies.

\section{Data Analysis}

Relative abundances among Stellifer species were compared using one-way ANOVA, where species was a factor and the total numbers of individuals collected each month were temporal replicates. Variations in their abundance over time (months) and space (South and North areas) were analyzed for each species separately by a factorial ANOVA. All ANOVA tests were assessed for their premises; in all cases the robustness of the test allowed its employment; a Student-Newman-Keuls (SNK) test was applied whenever the ANOVA tests were statistically significant (SOKAL; ROHLF, 1995; UNDERWOOD, 1997).

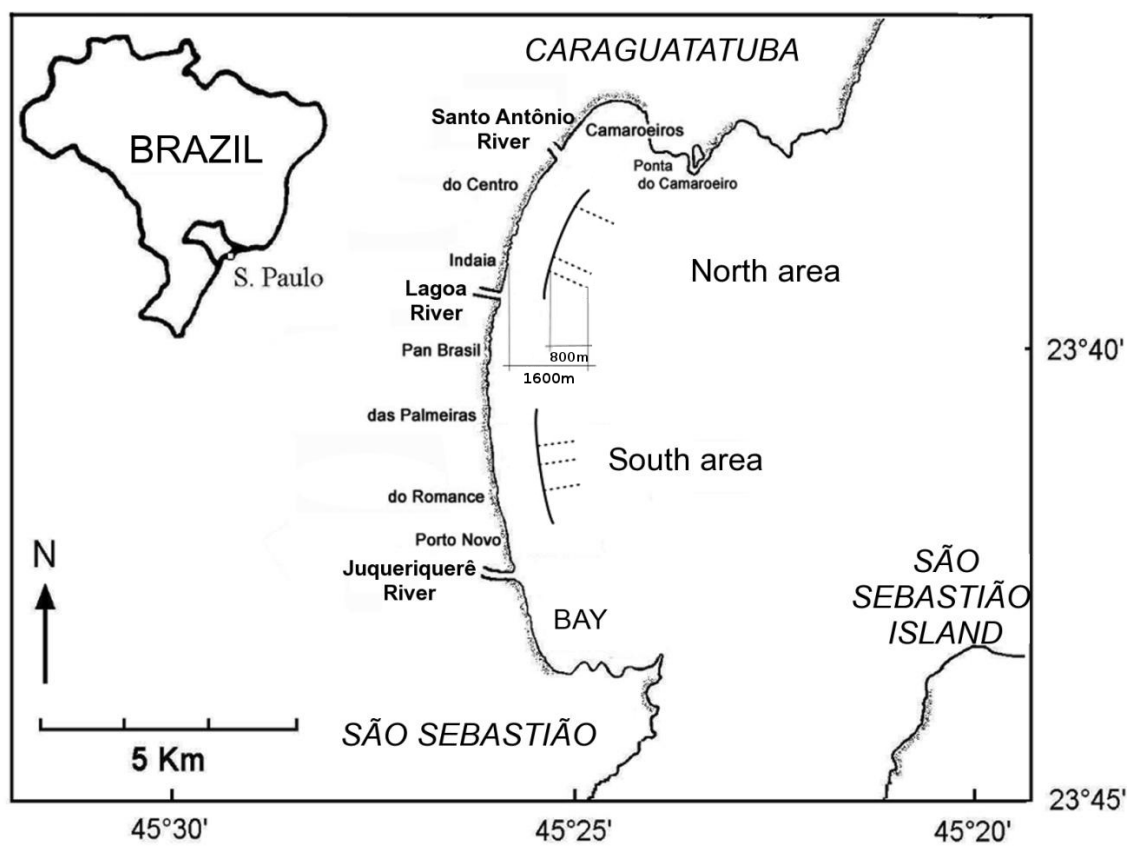

Fig. 1. Caraguatatuba Bay and otter-trawl sampling schemes from a monthly sample (dashed lines), in both study areas, North and South (solid lines). 
The same procedure was followed to compare the spatio-temporal total length (TL) variation of individuals: one-way ANOVA for comparisons among species, and factorial ANOVA for assessing each species over space and time.

Individuals were dissected to identify the sex and female gonad stage, according to Vazzoler (1996). The sex ratio of each species was compared over space and time with chi-squared tests. Expected values corresponded to $1: 1$ or to the general observed proportion, whenever it seemed more reasonable. It is important to note that for $S$. brasiliensis sexual analysis was seasonal and comprised 160 individuals, 40 being randomly selected for each season.

Total values of length (TL) and weight (TW) of all individuals were used in order to establish a weight-length relationship, as follows: $T W=a(T L)^{b}$ Outliers were excluded to improve the fit of the equation. Independent one-sample t-tests were used to assess whether or not parameters $a$ and $b$ were statistically different from 0 and 3, respectively. An ANCOVA was used for comparing a and b values among species.

Parameter a was interpreted as the population condition factor. The relative condition factor (Krel; LE CREN, 1951) was individually calculated using parameters a and $b$, from the weightlength relationship, which is expressed by the formula: Krel $=T W / a(T L)^{b}$. The values obtained were compared among species using one-way ANOVA. For each species, monthly values were compared using a twoway ANOVA. Pearson's correlation between total length and Krel values was performed for the three species.

\section{Results}

Relative Abundance, Spatio-temporal Distribution and Sexual Characterization:

Stellifer rastrifer comprised $87 \% \quad(\mathrm{n}=3183)$ of all individuals collected, S. brasiliensis $10 \%$ ( $\mathrm{n}=$ $357)$, and S. stellifer $3 \%(\mathrm{n}=116)$. There were also 13 individuals classified as Stellifer sp. (cf. MENEZES; FIGUEIREDO, 1980), which were not considered here because of their low proportion $(0.35 \%)$; these were caught in January, March, April and October of 2004. Differences in relative abundance of the Stellifer species were significant (ANOVA, $\mathrm{F}=18.47$; d.f $=2$; $\mathrm{p}<0.001$ ), and $S$. rastrifer was significantly more abundant than the other two $(227.36 \pm 48.55$ indiv. standard error; SNK, $\mathrm{p}<0.001$ for both comparisons). The difference in overall abundance between $S$. brasiliensis $(25.50 \pm 6.88$ indiv.) and $S$. stellifer $(8.29$ \pm 2.40 indiv.) was not significant ( $\mathrm{SNK}, \mathrm{p}=0.67$ ). Factorial ANOVA revealed that both space and time affected the distribution of numbers of individuals in almost all cases (Table 1). In general, most individuals of $S$. rastrifer and S. stellifer were collected in the South area, whereas $S$. brasiliensis was more equally distributed between areas. The three species showed no clear temporal pattern of variation, although an interaction between factors was discernible (Fig. 2, Table 1). Stellifer rastrifer was most abundant in April 2004 and S. stellifer in August 2003, both in the South area. For $S$. brasiliensis, the North area in October 2003 were the main area and month with a significantly higher number of individuals, followed by February 2004 in the South area, but in lower numbers.

Table 1. Results of factorial ANOVA for abundance and total length $(\mathrm{cm})$ distribution, for space (areas) and time (months), for Stellifer rastrifer, S. brasiliensis and S. stellifer. The fish were sampled in Caraguatatuba Bay from August 2003 to October 2004.

\begin{tabular}{|c|c|c|c|c|c|c|}
\hline \multirow{2}{*}{$\begin{array}{c}\text { Species/Source } \\
\text { of variation }\end{array}$} & \multicolumn{6}{|c|}{ Parameter } \\
\hline & \multicolumn{3}{|c|}{ Abundance } & \multicolumn{3}{|c|}{ Total Length (cm) } \\
\hline & $F$ & d.f. & $p$ & $F$ & d.f. & $p$ \\
\hline \multicolumn{7}{|l|}{ S. rastrifer } \\
\hline Time & 5.20 & 13 & $<0.001$ & 56.78 & 10 & $<0.001$ \\
\hline Space & 13.06 & 1 & $<0.001$ & 16.64 & 1 & $<0.001$ \\
\hline Interaction & 1.99 & 13 & 0.038 & 5.25 & 10 & $<0.001$ \\
\hline \multicolumn{7}{|l|}{ S. brasiliensis } \\
\hline Time & 5.48 & 13 & $<0.001$ & 7.85 & 9 & $<0.001$ \\
\hline Space & 0.13 & 1 & 0.716 & 0.04 & 1 & 0.830 \\
\hline Interaction & 5.77 & 13 & $<0.001$ & 2.16 & 9 & 0.020 \\
\hline \multicolumn{7}{|l|}{ S. stellifer } \\
\hline Time & 4.57 & 13 & $<0.001$ & 2.29 & 7 & 0.035 \\
\hline space & 9.33 & 1 & 0.003 & 6.40 & 1 & 0.010 \\
\hline interaction & 4.16 & 13 & $<0.001$ & 1.50 & 7 & 0.180 \\
\hline
\end{tabular}




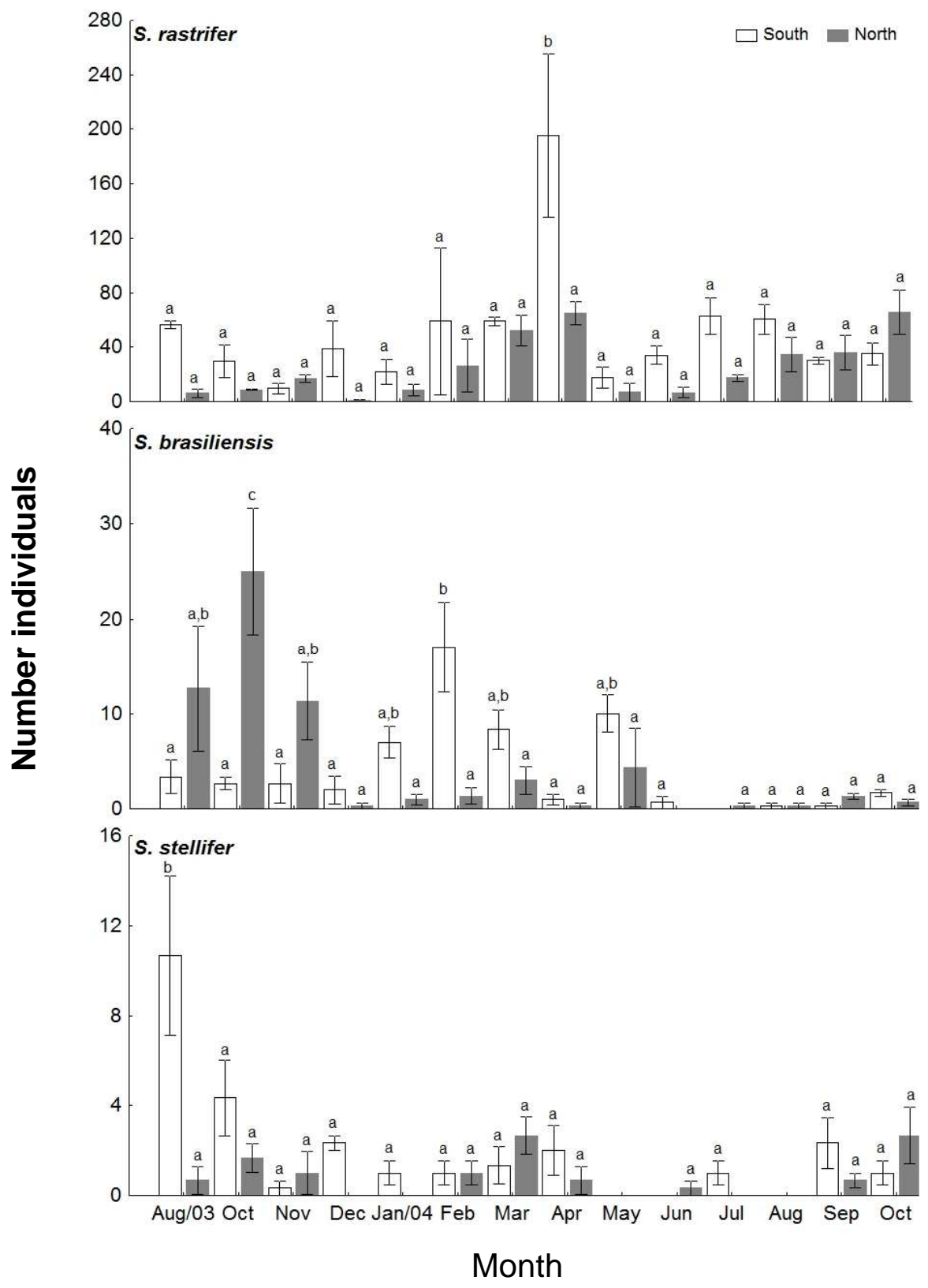

Fig. 2. Spatial and temporal variation in number of individuals (mean \pm standard error; $\alpha=0.05$ ) of Stellifer rastrifer, S. brasiliensis and S. stellifer, in Caraguatatuba Bay. Individuals were sampled from August/2003 to October/2004. Different letters denote significant differences among months and areas independently, discriminated by SNK test.

The species differed significantly in mean size $(\mathrm{F}=81.76 ; \mathrm{g} .1=2 ; \mathrm{p}<0.001)$. Stellifer rastrifer showed the greatest mean length $(8.49 \pm 0.04 \mathrm{~cm}$, standard error), S. stellifer the intermediate $(8.21 \pm$ $0.15 \mathrm{~cm})$, and $S$. brasiliensis the lowest $(7.57 \pm 0.08$ $\mathrm{cm}$; SNK, $\mathrm{p}<0.001$ for all comparisons). For $S$. rastrifer, two prominent length modes were observed, the first at approximately 7 to $9 \mathrm{~cm}$ and the second at approximately 11 to $12 \mathrm{~cm}$ (Fig. 3). The other two species each showed a single mode, also at approximately $7 \mathrm{~cm}$, although $S$. brasiliensis showed a more pronounced increase in the number of individuals from $5 \mathrm{~cm}$ on than did the other species. The factorial ANOVA also showed interaction 
between space and time in size distribution, except for S. stellifer (Table 1). Stellifer rastrifer was usually larger in the North area, except in August 2003, and April and May 2004. For S. brasiliensis the interaction was less pronounced, showing that month and area had some influence, but area alone did not show any differences in the mean number of individuals. Although no interaction was observed for S. stellifer, its mean size was always higher in the North area, except for August and October 2003.

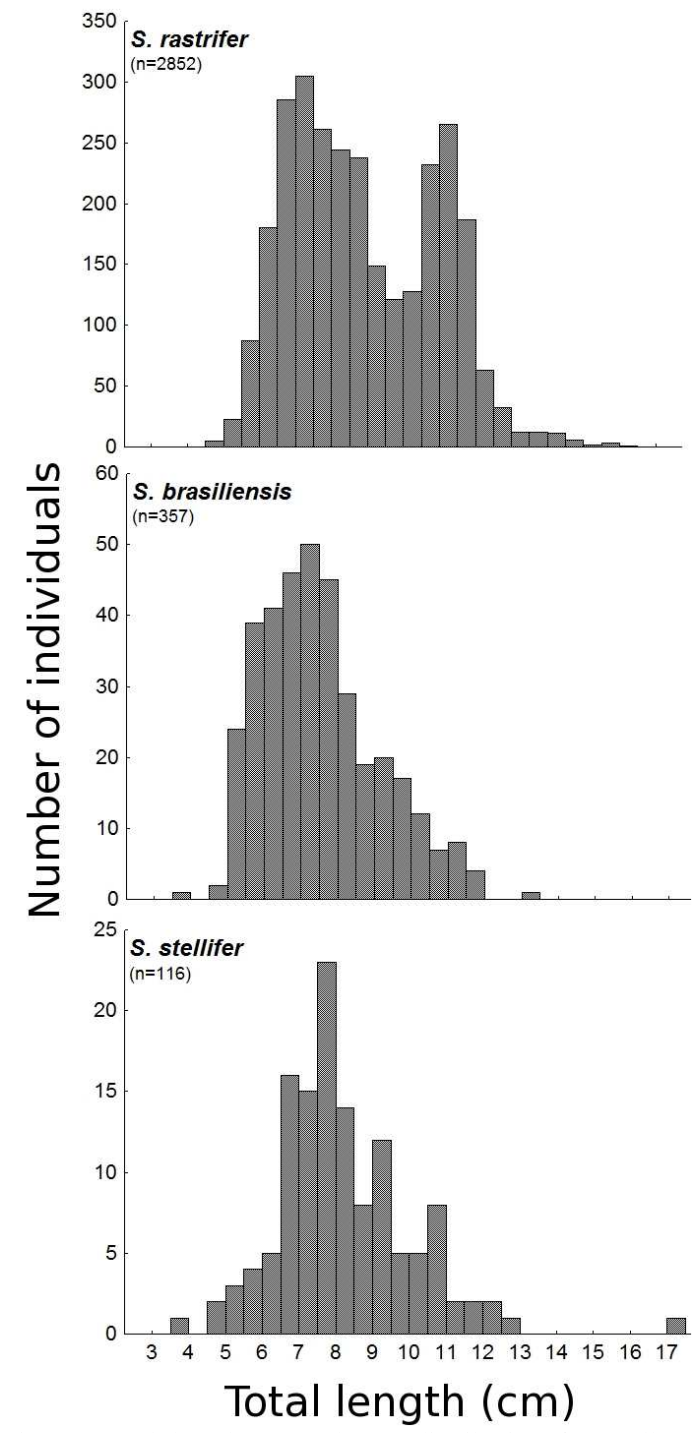

Fig. 3. Total length $(\mathrm{cm})$ classes distribution for Stellifer rastrifer, $S$. brasiliensis and $S$. stellifer, sampled in Caraguatatuba Bay from August/2003 to October/2004.
The total length distribution throughout the sampling period showed a very similar pattern for all the species (Fig. 4), with $S$. stellifer showing changes about a month earlier: an increase from August to November-December 2003 was followed by a slight reduction in mean size in the subsequent months. Then, a sharp increase occurred, attaining some of the highest mean values in April 2004, with a subsequent decline to the lowest observed values from June to August 2004. From September 2004 on, the values for mean size rose again, ending in the second length peak in October 2004.

The overall sex ratio was 1.26 males per female of $S$. rastrifer, and this proportion remained similar between areas $(\mathrm{X} 2=0.12$; d.f. $=1$; $\mathrm{p}=0.73$ ). Over the year, however, the sex ratio was significantly different from $1: 1(\mathrm{X} 2=65.17$; d.f. $=11$; $\mathrm{p}<0.001)$ due to April $(\mathrm{X} 2=44.24 ;$ d.f. $=1 ; \mathrm{p}<0.001)$ and May (X2=4.07; d.f.=1; $\mathrm{p}<0.05)$, both showing a $\mathrm{M}: \mathrm{F}$ ratio of 1.6:1. Females with immature gonads (A) comprised $80.94 \%$ of individuals, while $16.93 \%$ showed gonadal stage B, and $2.13 \%$ stage $\mathrm{C}$.

Stellifer brasiliensis and $S$. stellifer did not show a sex ratio significantly different from $1: 1$, for areas $(\mathrm{X} 2=2.34$; d.f. $=1 ; \mathrm{p}=0.13$ and $\mathrm{X} 2=0.32$; d.f. $=1$; $\mathrm{p}=0.57$, respectively $)$ or months $\left(\mathrm{X}^{2}=1.59\right.$; d.f. $=3$; $\mathrm{p}=0.66$ and $\mathrm{X}^{2}=17.25$; d.f. $\left.=11 ; \mathrm{p}=0.10\right)$. The highest proportion $(91.46 \%)$ of females in gonadal stage A was found for S. brasilensis. Stellifer stellifer had the highest proportion of females in gonadal stage B, $58.62 \%$, against $41.38 \%$ in stage A. No females in gonadal stage $\mathrm{C}$ were recorded for these last two species.

\section{Weight-length Relationship and Condition Factor}

The values obtained for parameters $a$ and $b$ from the weight-length relationships (Table 2), where $\mathrm{a}$ is the population condition factor and $\mathrm{b}$ the slope coefficient, were significant and different from 0 and 3 in all cases. ( $S$. rastrifer: ta $=43.65$; $\mathrm{tb}=37.25 ;$ d.f. $=2652$ / S. brasiliensis: ta=13.99; $\mathrm{tb}=6.23$; d.f. $=362$ / S. stellifer: $\mathrm{ta}=9.54 ; \mathrm{tb}=2.21$; d.f.=127). Similarly for all three species, these values indicated that the curves did not pass through the origin and growth was allometric. However, comparisons of the linearized equation for the weightlength relationship among species showed that they differed significantly from each other, both for parameters a and b (ANCOVA: slope (b): $F=171.1$; d.f. $=2 ; \quad p<0.001 /$ intercept (a): $F=70537.6 ; \quad$ d.f. $=1$; $\mathrm{p}<0.001)$. 

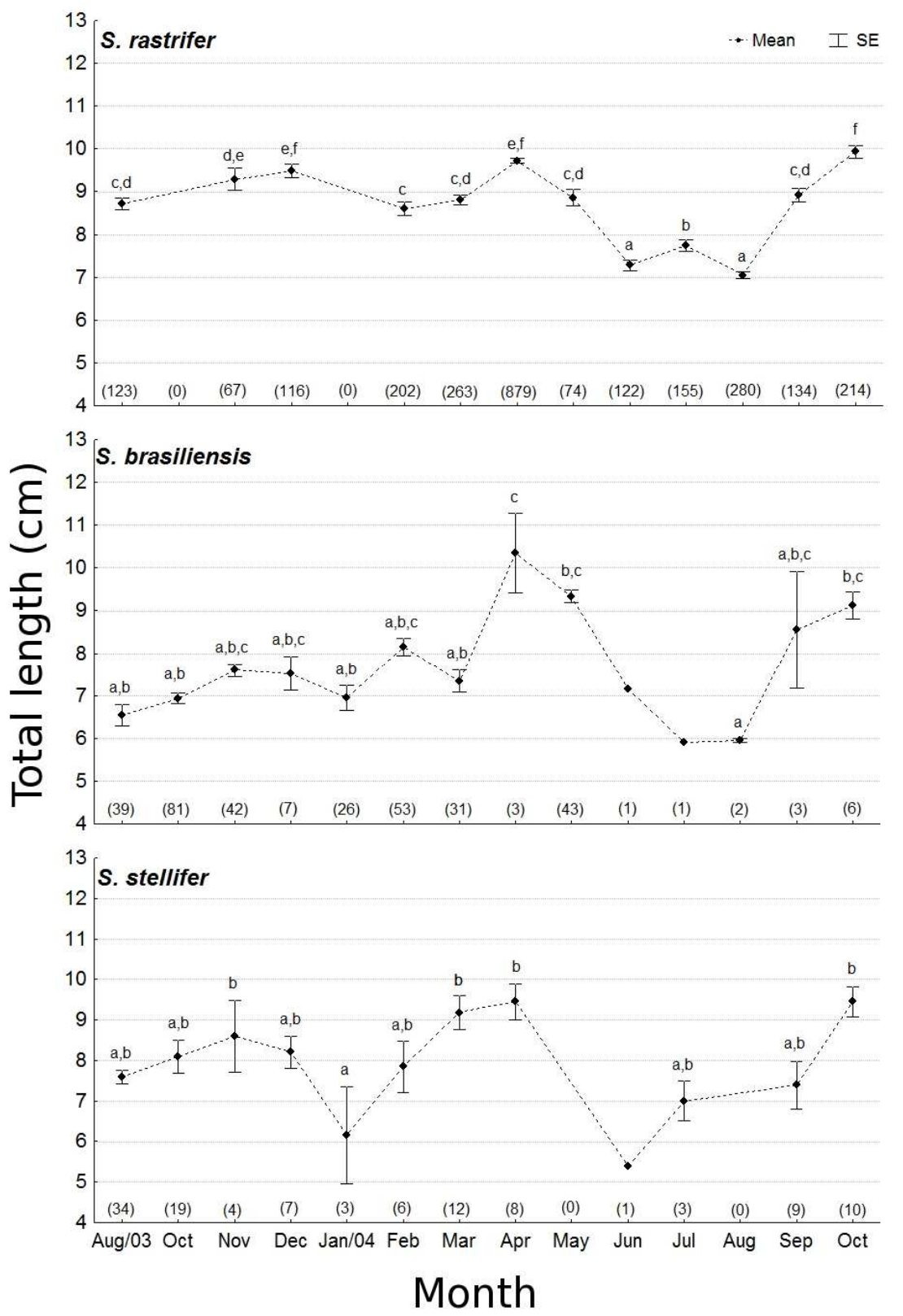

Fig. 4. Temporal variation of total length $(\mathrm{cm}$; mean \pm standard error; $\alpha=0.05)$ for Stellifer rastrifer, $S$. brasiliensis and S. stellifer sampled in Caraguatatuba Bay from August to October/2004. Different letters denote significant differences among months, discriminated by SNK test; brackets on the X-axis enclose the number of observations in each case.

The Krel values differed significantly over months for S. rastrifer $(\mathrm{F}=16.61$; d.f. $=11 ; \mathrm{p}<0.001)$ and $S$. brasiliensis $(\mathrm{H}=47.61$; d.f. $=11 ; \mathrm{p}<0.001)$, but not for S. stellifer $(\mathrm{F}=1.61$; d.f. $=10 ; \mathrm{p}=0.107)$. Since the Krel values remained close to 1 throughout the year, any temporal pattern of variation was too subtle to identify (Fig. 5). Still, the relative condition factor and total-length values were negatively correlated, although with coefficients lower than $|0.4|$, i.e., relatively low $(S$. rastrifer $\mathrm{r}=-0.30, \mathrm{p}<0.001 ; S$. brasiliensis $\mathrm{r}=-0.36, \mathrm{p}<0.001 ; S$. stellifer $\mathrm{r}=-0.21$, $\mathrm{p}<0.05)$. It is not surprising, therefore, that the mean values for the relative condition factor (Krel; LE CREN, 1951) showed significant differences among 
Table 2. Values for parameters a and b, and the respective standard error, for adjusted total weight $(\mathrm{g})$ and length $(\mathrm{cm})$ for Stellifer rastrifer, S. brasiliensis and S. stellifer, sampled in Caraguatatuba Bay, from August 2003 to October 2004.

\begin{tabular}{llccc}
\hline Species & \multicolumn{4}{c}{ Parameter } \\
\hline \multicolumn{2}{c}{$\mathbf{N}$} & $\boldsymbol{a}$ & $\boldsymbol{b}$ & $\mathbf{r}^{\mathbf{2}}$ \\
\hline S. rastrifer & 2852 & $0.0053 \pm 0.0001$ & $3.3503 \pm 0.0094$ & 0.9914 \\
S. brasiliensis & 357 & $0.0066 \pm 0.0004$ & $3.1960 \pm 0.0315$ & 0.9830 \\
S. stellifer & 116 & $0.0085 \pm 0.0009$ & $3.0999 \pm 0.0452$ & 0.9878 \\
\hline
\end{tabular}

species (ANOVA: $\mathrm{F}=14.54$; d.f. $=2 ; \mathrm{p}<0.001$ ), where $S$. brasiliensis had a higher mean value $(1.04 \pm$ $0.0084)$ than both $S$. rastrifer $(1.03 \pm 0.0021$; SNK, $\mathrm{p}<0.001)$ and $S$. stellifer $(1.01 \pm 0.0132 ; \mathrm{SNK}$, $\mathrm{p}<0.001)$, which were similar to each other $(\mathrm{SNK}$, $\mathrm{p}=0.235)$

\section{DisCUSSION}

Despite the differences in relative abundance and overall mean size among the three species, they all showed similar variations in size throughout the year in the study area, as well as similar relationships between size and their relative condition factor, i.e., significant negative correlations. Also, the area seems to have some peculiarities concerning the species size distribution, suggesting that it has special features for these species' biology.

Stellifer rastrifer was not only the most abundant species of its genus but also of its family (Sciaenidae), in addition to being one of the most important in Caraguatatuba Bay (unpublished data) as in other Brazilian areas (GIANINNI; PAIVA-FILHO, 1990a; SANTOS et al., 2002; BARLETTA et al., 2005, 2008; CAMARGO; ISAAC, 2005). Monitoring species relative abundance, especially the numerically important ones, may provide important information about environmental changes. For example, Stellifer lanceolatus in Campeche Bay, Mexico, showed a substantial relative increase from 1980 to 1998-1999, which was thought to be a possible consequence of anthropogenic actions (RAMOS-MIRANDA et al., 2005). The gathering of useful data for monitoring purposes requires long temporal sampling series, which would be more viable using discarded bycatch species from shrimp fisheries. However, such a method requires particular environmental and species conditions, such as those observed and further discussed here, to be already well known and taken into account. With respect to the spatio-temporal abundance in species distribution, the South area, which is more influenced by continental waters, tended to have larger numbers of individuals, except for $S$. brasiliensis, which was more equally distributed between areas in all sampling periods

The mean size varied significantly among the species, as was apparent from the different asymmetries observed in the overall length-frequency distribution. However, the mean size was somewhat similar among them, because in all cases individuals below and above a size range were clearly missing, especially considering that the second length mode observed for $S$. rastrifer was actually highly influenced by the data for April 2004. For this species, the April data differed significantly from those of other months as to the number of individuals and mean total length, so that the observed bimodal length distribution seems not to represent the coexistence of two cohorts with similar numbers of individuals, but rather a large influx of individuals at that time, mainly larger fish than those usually found in the area.

Although the lack of size categories could be explained in many ways, it is most probable that the area attracts individuals of a limited size range. Our reasons for this assumption are that (i) segregation by size according to depth has been shown to occur in other sciaenids (FENESSY, 2000); (ii) such an abrupt decrease in size classes above 8-9 $\mathrm{cm}$ would not be an acceptable natural mortality rate for species maintenance; (iii) different species showed different overall length-frequency distributions, i.e., $S$. brasiliensis showed more smaller individuals and $S$. rastrifer more larger individuals, so that net selectivity was not an obstacle for sampling different sizes of individuals; and (iv) shrimp trawling was prohibited from March 1 to May 31 during the sampling period, so that selective overexploitation could explain, for example, the peak in abundance of $S$. rastrifer in April, but would not explain the abrupt decrease in abundance in May, or the peaks in mean size in November-December 2003 and October 2004. 


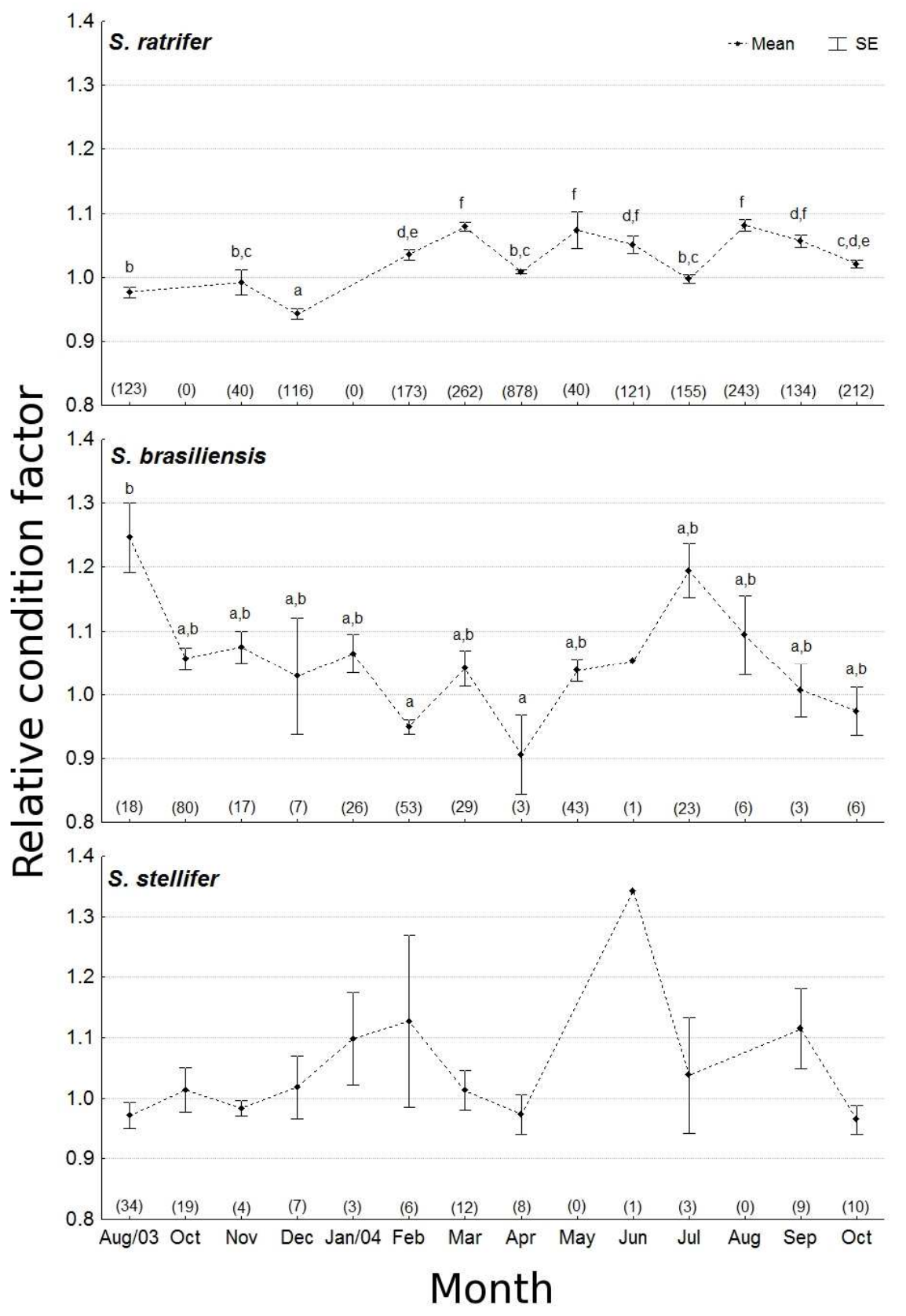

Fig. 5. Temporal variation of the relative condition factor (Krel; mean \pm standard error; $\alpha=0.05$ ) for Stellifer rastrifer, S. brasiliensis and S. stellifer sampled in Caraguatatuba Bay from August/2003 to October/2004. Different letters denote significant differences among months, discriminated by SNK test; brackets on the $\mathrm{x}$ axis enclose the number of observations in each case. 
In general, these data indicate that, if individuals of different size classes were not properly sampled, it is likely that they were not there. However, these missing individuals must be presumed to be present in higher concentrations somewhere else, suggesting that, somehow, all three species segregate their individuals by size. These results tend to confirm a suggestion by Coelho et al. $(1985,1987)$ for $S$. rastrifer and $S$. brasiliensis, that individuals stratify by length classes, and this stratification would probably increase with depth. If such a stratification does occur, one could expect to find smaller individuals in shallower or estuarine areas.

In fact, the overall length fluctuation suggests that the three species use the area in a very similar way over time. For example, abrupt increases in length were recorded throughout the sampling period for all species at similar times, indicating that larger individuals may periodically enter the area. The entry of larger individuals to innermost estuarine areas during dry seasons had previously been observed by Camargo and Isaac (2005) and Figueiredo-Fonseca and Lobão de Souza (2006). Increases in salinity would reduce the physiological stress on the fish at other times, since older individuals seem to be less tolerant of lower salinities (BARLETTA-BERGAN et al., 2002). However, in the present study, peaks of mean size did not occur only during dry periods, such as autumn 2004, but also in late spring 2003 and midspring 2004. These peaks concord with reproductive peaks previously reported for these species (ALMEIDA; BRANCO, 2002; SOUZA; CHAVES, 2007). Therefore, abrupt increases in mean length may also represent the entry of mature individuals during reproductive periods, in order to reach ideal spawning areas (nearer the estuary mouth). Newly hatched larvae and adults are less resistant to lower salinities (BARLETTA-BERGAN et al., 2002; BONECKER et al., 2007), and physiological stress in the estuarine environment is apparently better tolerated by young individuals (CAMARGO; ISAAC, 2005).

Of the three species, the population of $S$. stellifer seems to undergo size fluctuations one month earlier than the others. Barletta and Barletta-Bergan (2009) suggested that S. rastrifer and S. stellifer had different breeding seasons, because of the observed temporal differences in the abundance of their larvae, supporting the suggestion that the highest and lowest observed peaks may be related to recruitment and reproductive events.

Environmental features, such as salinity, may also be responsible for the spatial differences observed here. If juveniles move toward areas of greater oceanic influence as they mature, it is reasonable to expect to find smaller individuals in the South area. Recent observations have indicated that a salinity decrease leads to a reduction in the mean size of individuals, at least for $S$. rastrifer and $S$. brasiliensis (CAMARGO; ISAAC, 2005; SCHWARZ et al., 2006; BARLETTA et al., 2008). Consequently, the higher abundance in the same area is explicable as due to smaller individuals having passed through a shorter recruitment period, so that they would be more numerous than slightly larger ones, which were found mostly in the North area. Interestingly, the months when larger mean sizes were observed in the South area correspond to the months when larger individuals entered. This seems reasonable, considering that if they are moving toward more estuarine regions for some reason, they would be more affected by the estuary of a larger river.

Although the weight/length relationship differed significantly among these three species, it appears quite similar compared to the data presented in the literature (Table 3) so that it does not seem appropriate to assume that there was any difference in health conditions among the species based on the values for parameter a. Parameter $b$, in turn, indicated that all three species show positive allometry during development. We note that $\mathrm{b}$ values slightly above 3 are normal, because investment in gonadal development by adults usually makes their bodies thicker (FROESE, 2006). However, differences from other published data must be carefully considered, because differences not only in population characteristics but also in the study area and the methods used for sampling and analysis may cause biases in the data, especially considering the species population features addressed here. Therefore, it is extremely important to properly describe and standardize the methods used, in order, as far as possible, to avoid methodological biases, so as to provide a reliable basis to question effectively whether environmental characteristics are influencing these animals' biology. Similarly, the temporal variations in the Krel values that were shown by all the species, although they are statistically significant, may have no biological meaning, since the means ranged only from 0.9 to 1.0 in all cases. As it was significantly and negatively correlated with total length, i.e., lower Krel values were found in the months with higher mean total length and vice versa, the Krel variation over the year may be considered, at least in part, to be the result of differences in the size structure of the population. It is very unlikely that changes in the health of the fish would cause for Krel variations over time. Because the values of the condition factor are strongly influenced during peaks of maximum reproductive activity and spawning (VAZZOLER, 1996; CHAVES; VENDEL, 1997), these minor changes may be another indication that the study area is used somehow by mature individuals (as well as for the development and feeding of juveniles), but not as a spawning ground. 
Table 3. Values of parameters a and $b$ from the length- weight relationship found in published references, as well as the results of the present study. Respective values of minimum, maximum and mode of total length, and locations where studies were undertaken, are shown. *n.a. - not available.

\begin{tabular}{|c|c|c|c|c|c|c|}
\hline \multirow{2}{*}{$\begin{array}{l}\text { Species/Source } \\
\text { of variation }\end{array}$} & \multicolumn{6}{|c|}{ Parameter } \\
\hline & Author & $\mathbf{a}$ & b & $\operatorname{Min}-\max (\mathbf{c m})$ & Mode $(\mathrm{cm})$ & Local \\
\hline \multirow[t]{7}{*}{ S. rastrifer } & Coelho (1985) & $9.0 * 10^{-3}$ & 3.12 & $4.0-17.0$ & 7.0 and 9.0 & Various/SP \\
\hline & $\begin{array}{l}\text { Gianinni and Paiva-Filho } \\
\text { (1990b) }\end{array}$ & $7.2 * 10^{-6}$ & 3.13 & $4.0-20.0$ & 8.0 & Santos/SP \\
\hline & Chaves and Vendel (1997) & $4.6 * 10^{-6}$ & 3.22 & $\approx 5.5-17.2$ & 12.0 & Guaratuba/PR \\
\hline & Isaac and Moura (1998) & $2.9 * 10^{-3}$ & 3.51 & $6.7-14.7$ & n.a. & Bragança/PA \\
\hline & Figueiredo-Fonseca and & $9.8 * 10^{-3}$ & 2.93 & $1.9-11.4$ & n.a. & Bragança/PA \\
\hline & Lobão de Souza (2006) & & & & & \\
\hline & This study & $5.3 * 10^{-3}$ & 3.35 & $4.0-16.0$ & 7.0 and & Caraguatatuba/SP \\
\hline \multirow[t]{5}{*}{ S. brasiliensis } & Braga (1986) & $4 * 10^{-3}$ & 3.35 & $5.2-16.7$ & $\approx 10.0$ & Ilha Anchieta/SP \\
\hline & Coelho (1987) & $1.8 * 10^{-2}$ & 2.80 & $3.0-18.0$ & $7.0-8.5$ & Various/SP \\
\hline & $\begin{array}{l}\text { Gianinni and Paiva-Filho } \\
\text { (1995) }\end{array}$ & $2.4 * 10^{-6}$ & 3.03 & $3.5-22.6$ & 9.5 & Santos/SP \\
\hline & Freire et al. (2009) & $6.4 * 10^{-3}$ & 3.21 & $4.0-16.1$ & n.a. & Various/BA \\
\hline & This study & $6.6 * 10^{-3}$ & 3.20 & $4.0-13.1$ & 7 & Caraguatatuba/SP \\
\hline \multirow[t]{4}{*}{ S. stellifer } & Almeida and Branco (2002) & $7.3 * 10^{-3}$ & 3.14 & $3.7-17.7$ & n.a. & Penha/SC \\
\hline & $\begin{array}{l}\text { Figueiredo-Fonseca and } \\
\text { Lobão de Souza (2006) }\end{array}$ & $6.9 * 10^{-3}$ & 3.06 & $1.6-12.9$ & n.a. & Bragança/PA \\
\hline & Freire et al. (2009) & $1.1 * 10^{-2}$ & 2.93 & $2.0-9.9$ & n.a. & Various/BA \\
\hline & This study & $8.5 * 10^{-3}$ & 3.10 & $3.8-12.6$ & 7.5 & Caraguatatuba/SP \\
\hline
\end{tabular}

In summary, the number of similar characteristics observed among the three species seem to constitute a successful survival strategy that has not changed greatly during the speciation process. These characteristics may eventually allow a combined use of these population parameters as an environmental indicator, facilitating the development of management strategies. Moreover, the present study strongly suggests that this strategy includes a stratification by size in these populations, even though it is not precisely linear or related only to depth. If so, larger individuals migrate out of this area and return sporadically. The study area includes parts of the bay that are less influenced by continental waters, and were shown to be essential for later phases of the development of juveniles. For management purposes, it is important to consider that more intense exploitation of this kind of area may affect different age groups of these populations unequally.

\section{ACKNOWLEDGEMENTS}

This work was partially financed by the State of São Paulo Research Foundation (FAPESP) within the Biota/FAPESP - The Biodiversity Virtual Institute Program (www.biota.org.br). We also thank FAPESP for the "Programa Jovem Pesquisador em Centro Emergente" grant offered to M. R. D. (Proc. No. 05/60041-6 and 06/57575-1), and the scholarship offered to M. P. (Proc. No. 07/56738-7). The Project Aware Foundation and Padi Foundation also financed part of this research project. Essential logistical support was provided by the Instituto Costa Brasilis -
Desenvolvimento Sócio-Ambiental and the University Center of the Fundação de Ensino Octávio Bastos. We are grateful to M.Sc. Eduardo Bessa and Dr. Flávia Borges for their assistance in the sampling and laboratory activities, including taxonomic identification. We also thank Alessandra P. Majer, Gustavo M. Dias, and Cynthia G. M. Delboni for their assistance in the fieldwork, and Renata Nastrini for laboratory work. Thanks to Dr. Janet W. Reid (JWR Associates) for revising the English text.

\section{REFERENCES}

ALMEIDA, L. R.; BRANCO, J. O. Aspectos biológicos de Stellifer stellifer na pesca artesanal do camarão setebarbas, Armação do Itapocoroy, Penha, Santa Catarina, Brasil. Revta. Brasil. Zool., v. 19, n. 2, p. 601-610, 2002.

ASMUS, M.; KITZMANN, D. Gestão costeira no Brasil estado atual e perspectivas (versão preliminar). Rio Grande, RS: Fundação Universidade do Rio Grande. 63 p. 2004.

BARLETTA, M. et al. Seasonal changes in density, biomass, and diversity of estuarine fishes in tidal mangrove creeks of the lower Caeté Estuary (northern Brazilian coast, east Amazon). Mar. Ecol. Prog. Ser., v. 256, p. 217-228, 2003.

BARLETTA, M. et al. The role of salinity in structuring the fish assemblages in a tropical estuary. J. Fish Biol., v. 66, p. 45-72, 2005.

BARLETTA, M. et al. Factors affecting seasonal variations in demersal fish assemblages at an ecocline in a tropicalsubtropical estuary. J. Fish Biol., v. 73, p. 1314-1336, 2008. 
BARLETTA, M.; BARLETTA-BERGAN, A. Endogenous activity rhythms of larval fish assemblages in a mangrove-fringed estuary in North Brazil. The Open Fish Sci. J., v. 2, p. 15-24, 2009.

BARLETTA-BERGAN, A.; BARLETTA, M.; SAINTPAUL, U. Structure and easonal Dynamics of Larval Fish in the Caete River Estuary in North Brazil. Estuar. Coast. Shelf Sci.., v. 54, p. 193-206, 2002.

BONECKER, A. C. T. et al. Larval fish composition of a tropical estuary in northern Brazil (2018' 2o47'S/044o20'- 044o25'W) during the dry season. Pan Am. J. Aquat. Sci., v. 2, n. 3, p. 235-241, 2007.

BRAGA, F. M. S. Estudo entre fator de condição e relação 112 peso/comprimento para alguns peixes marinhos. Revta. Brasil. Biol., v. 46, n. 2, p. 339-346, 1986.

BRANCO, J.O.; VERANI, J. R. Quali-quantitative analysis of sea-bob-shrimp's ichthyofauna bycatch, at Armação do Itapocoroy, Penha, Santa Catarina. Revta. Brasil. Zool., v. 23, n. 2, p. 381-391, 2006.

CAMARGO, M.; ISAAC, V. J. Reproductive biology and spatio-temporal distribution of Stellifer rastrifer, Stellifer naso and Macrodon ancylodon (Sciaenidae) in the Caeté Estuary, Northern Brazil. Braz. J. Oceanogr., v. 53, n. 1-2, p. 13-21, 2005.

CHAVES, P. T .C.; VENDEL, A. L. Reprodução de Stellifer rastrifer (Jordan) (Teleostei, Sciaenidae) na Baía de Guaratuba, Paraná, Brasil. Rev.Bras.Zool., v. 14 n. 1, p. 81-89, 1997.

COELHO, J. A. P. et al. Relação peso-comprimento e tamanho de início de primeira maturação gonadal para o Sciaenidae Stellifer rastrifer (Jordan, 1889), no litoral do estado de São Paulo. Bol. Inst. Pesca, v. 12, n. 2, p. 99107,1985

COELHO, J. A. P. et al. Aspectos biológicos e pesqueiros do Sciaenidae Stellifer brasiliensis (Schultz, 1945) presente na pesca artesanal dirigida ao camarão sete-barbas (São Paulo, Brasil). Bol. Inst. Pesca, v. 14, p. 1-10, 1987.

FENNESSY, S. T. Aspects of the biology of four species of Sciaenidae from the East Coast of South Africa. Estuar. Coast. Shelf Sci., v. 50, p. 259-269, 2002.

FIGUEIREDO-FONSECA, A.; LOBÃO DE SOUZA, R. A Relações morfométricas de algumas espécies de peixes da fauna acompanhante capturada nas pescarias artesanais do camarão em região estuarina do rio Taperaçu (Bragança-PA-Brasil). Bol. Téc. Cient. Cepnor, Belém, v. 6, n. 1, p. 79-87, 2006.

FLORES-COTO, C. et al. Abundance seasonal variation of larval Sciaenidae in Campeche Bay, Mexico. Rev. Investig. Mar., v. 25, n. 1, p. 45-56, 2004.

FREIRE, K. M. F.; ROCHA, G. R. A. ; SOUZA, I. L. Length-weight relationships for fishes caught by shrimp trawl in southern Bahia, Brazil. J. Appl. Ichthyol., v. 25, p. 356-357, 2009

FROESE, R. Cube law, condition factor and weight-length relationships: history, meta-analysis and recommendations. J. Appl. Ichthyol., v. 22, p. 241-253, 2006.

GIANINNI, R.; PAIVA-FILHO, A. M. Os Sciaenidae (Teleostei, Perciformes) da Baía de Santos (SP), Brasil. Bol. Inst. Oceanogr., v. 38, n. 1, p. 69-86, 1990a.

GIANINNI, R.; PAIVA-FILHO, A. M. Aspectos bioecológicos de Stellifer rastrifer (Perciforme, Sciaenidae) na Baía de Santos, SP. Bol. Inst. Oceanogr., v. 38 , n. 1, p. 57-67. 1990 b.
GIANINNI, R.; PAIVA-FILHO, A. M. Distribuição temporal, espacial e bioecologia do Cangoá Stellifer brasiliensis (Teleostei, Sciaenidae), na Baía de Santos, São Paulo, Brasil. Arq. Ciên. Mar, v. 29, n. 1-2, p. 513, 1995.

ISAAC, V. J.; MOURA, U. S. The food consumption rate of three populations of fish of the estuary of the Caeté River, Bragança municipality, state of Pará, on the northern coast of Brazil. Bolm. Mus. Paraense Emilio Goeldi, v. 14, n. 1, p. 57-75, 1998. (Série Zoologia).

LE CREN, E. D. The length-weight relationship and seasonal cycle in gonad weight and condition in the perch (Perca fluviatilis). J. Anim. Ecol., v. 20, p. 201-219, 1951.

MENEZES, N. A.; FIGUEIREDO, J. L. Manual de peixes marinhos do sudeste do Brasil .IV. (Teleostei 3). São Paulo: Museu de Zoologia, Universidade de São Paulo, 1980. 90p.

PAIVA-FILHO, A. M.; SCHMIEGELOW, J. M. M. Fish bycatch from shrimp fishery Xyphopenaeus kroyeri in the Bay of Santos, Sao Paulo, Brazil I. quantitative studies. Bol. Inst. Oceanogr., v. 34, p. 79-85, 1986.

RAMOS-MIRANDA, J. et al. Spatial and temporal changes in the nekton of the Terminos Lagoon, Campeche, Mexico. J. Fish Biol., v. 66, p. 513-530, 2005.

SANTOS, C. et al. A ictiofauna em duas planícies de maré do setor eurihalino da Baía de Paranaguá, PR. Bol. Inst. Pesca, v. 28, n. 1, p. 49-60, 2002.

SASAKI, K. Phylogeny of the family Sciaenidae, with notes on its zoogeography (Teleostei, Perciformes). Mem. Fac. Fish., Hokkaido University, v. 36, n. 1-2, p. 1-137, 1989.

SCHWARZ J.R. et al. Composition and structure of the demersal ichthyofauna in the Pinheiros Bay, Paraná, Brazil. Braz. J. Aquat. Sci., Techn., v. 10, n. 1, p. 2739, 2006.

SOKAL, R. R.; ROHLF, J. F. Biometry: The principles and practice of statistics in biological research. 3. ed. New York: W. H. Freeman,1997. 850 p.

SOUZA, L. M.; CHAVES, P. T. Reproductive activity of fish (Teleostei) and closed season to shrimp trawling off the northern coast of Santa Catarina Brazil. Rev. Bras. Zool., v. 24, n. 4, p. 1113-1121, 2007.

UNDERWOOD, A. J. Experiments in ecology: their logical design and interpretation using analysis of variance. Cambridge: Cambridge University Press, 1997. 504 p.

UPCHURCH, S.; WENNER, E. Fish and decapod Crustacean assemblages from the Ashepoo-CombaheeEdisto Basin, South Carolina (1993-1999). J. Coast. Res., p. 200-213, 2008

VAZZOLER, A. E. A. M. Biologia da Reprodução de Teleósteos: Teoria e Prática. Maringá, PR: Eduem, 1996. $169 \mathrm{p}$.

VIANNA, M.; ALMEIDA, T. Bony fish bycatch in the Southern Brazil pink shrimp (Farfantepenaeus brasiliensis and F. paulensis) fishery. Braz. Arch. Biol. Technol., v. 48, n. 4, p. 611-623, 2005.

WALTHER, G. R.; POST, E.; CONVEY, P. MENZEL A., PARMESAN, C.; BEEBEE, T. J. C.; FROMENTIN, J. M.; HOEGH-GULDBERG, O.; BAIRLEIN, F. Ecological responses to recent climate change. Nature, v. 416, p. 389-395, 2002.

(Manuscript received 13 September 2010; revised 27 April 2012; accepted 21 June 2012) 